DOI: https://doi.org/10.47405/mjssh.v5i2.363

\begin{tabular}{|c|c|}
\hline 4 & Malaysian Journal of Social Sciences and Humanities (MJSSH) \\
\hline $\begin{array}{l}\text { Malaysian Journal of } \\
\text { Social sciences and }\end{array}$ & Volume5, Issue 2, February 2020 \\
\hline (MJ-SSH) & e-ISSN : 2504-8562 \\
\hline & $\begin{array}{l}\text { Journal home page: } \\
\text { www.msocialsciences.com }\end{array}$ \\
\hline
\end{tabular}

\title{
Pertahanan Menyeluruh (HANRUH) di dalam Sistem Pertahanan Malaysia
}

\author{
Muhamad Ridzuan Bin Hashim ${ }^{1}$, Mohamad Faisol Keling1, Nazariah Osman' \\ ${ }^{1}$ College of Law, Government and International Studies, Universiti Utara Malaysia (UUM) \\ Correspondence: Mohamad Ridzuan Hashim (ridzuanhshm@yahoo.com)
}

\begin{abstract}
Abstrak
Senario ancaman keselamatan ketika dan selepas Perang Dingin telah mempengaruhi Malaysia untuk membangunkan aspek pertahanan dan keselamatan negara. Ia adalah satu bentuk keperluan kepada Malaysia bagi memastikan keselamatan dan kedaulatan negara terjamin. Justeru Malaysia telah membangunkan aspek pertahanan semenjak tahun 1957 dan semakin berkembang mengikut perkembangan ancaman semasa. Dalam memastikan matlamat ini tercapai Malaysia telah menumpukan kepada pembangunan Dasar Pertahanan dengan memperkenalkan konsep Pertahanan Menyeluruh (HANRUH) yang merupakan konsep pertahanan yang diamalkan oleh kebanyakan negara sama ada di Asia Tenggara, Asia dan Eropah. Artikel ini menjelaskan proses pembangunan Dasar Pertahanan Negara (DPN) melalui peranan kerajaan khususnya ATM dalam melaksanakan pertahanan menyeluruh iaitu HANRUH di negara ini.
\end{abstract}

Kata kunci: Dasar Pertahanan Negara (DPN), HANRUH, Angkatan Tentera Malaysia (ATM)

\section{Total Defense (HANRUH) in the Malaysian Defense System}

\begin{abstract}
The scenario of security threats during and after the Cold War has influenced Malaysia to develop national defense and security aspects. It is a necessary condition for Malaysia to ensure the security and sovereignty of the nation. Thus, Malaysia has been developing defense aspects since 1957 and is growing in line with current threats. In ensuring that this is achieved Malaysia has focused on the development of the Defense Policy by introducing the concept of Total Defense (HANRUH) which is a concept of defense practiced by most countries in Southeast Asia, Asia and Europe. This article explains the process of developing the National Defense Policy (NDP) through the role of the government especially ATMs in implementing the comprehensive defense of HANRUH in the country.
\end{abstract}

Keywords: National Defense Policy (DPN), HANRUH, Malaysian Armed Forces (ATM) 


\section{Konsep Pertahanan Menyeluruh}

Menurut Nasibah Harun (1997) dalam artikelnya Dasar Pertahanan Menyeluruh, konsep HANRUH ini telah diamalkan oleh banyak negara seperti Sweden ${ }^{1}$, Denmark, Finland, Singapura, Indonesia ${ }^{2}$, Singapura, Switzerland dan sebagainya yang dikenali sebagai total defence, namun ianya berbeza dari segi pendekatan namun tujuannya adalah sama iaitu menggembeleng semua aset dan kekuatan negara dari segi ekonomi, sosial, politik, psikologi dan pertahanan awam di samping memperkukuhkan sistem pertahanan ketenteraan bagi mengukuhkan sistem pertahanan negara ${ }^{3}$. Kerajaan melihat HANRUH ini sebagai satu konsep bagi melengkapkan dan memantapkan prinsip pertahanan berdikari dalam DPN. Menurut Hamzah Dollah (2006, p. 52) dalam Pembangunan Pertahanan Malaysia-Satu Pendekatan Menyeluruh menyatakan :-

"HANRUH boleh diterjemahkan sebagai pasukan yang mengkucar
kacirkan sekali gus melemahkan pasukan kecil musuh yang sudah
bertapak atau menawan tanahair. Maksudnya mungkin pada satu ketika
kekuatan ketumbukan ATM (Angkatan Tentera Malaysia) tidak berjaya
menghalang kehadiran angkatan tentera musuh dalam kekuatan yang ramai
sekali gus tanah air ditawan. Pada masa ini kekuatan musuh akan
dikecilkan untuk memenuhi penempatan yang menyeluruh di seluruh
negeri. Waktu sebeginilah peranan komuniti bukan tentera yang telah
dilatih sebelum ini menjalankan aktiviti sabotaj dan sebagainya. Inilah
konsep HANRUH yang diperkenalkan oleh pihak tertinggi ATM dalam
usaha untuk memperkasakan pertahanan"4.

Menurut Zulkefale A.Rahman (1998) dalam Angkatan Tentera Malaysia: Arah Baru Menghadapi Cabaran Abad ke 21, konsep strategi pertahanan menyeluruh berkait rapat dengan usaha total dan bersepadu yang dilaksanakan oleh kerajaan, agensi bukan kerajaan, sektor swasta dan rakyat jelata dalam mempertahankan negara. Pemeliharaan keutuhan dan kedaulatan Malaysia memerlukan komitmen semua lapisan rakyat dan tidak hanya oleh angkatan Tentera. Strategi pertahanan menyeluruh adalah strategi yang melibatkan tanggungjawab golongan tentera dan bukan tentera dalam mempertahankan keselamatan dan kedaulatan negara. Walaupun tugas mempertahankan negara merupakan tanggungjawab pasukan keselamatan, namun kewajipan untuk memastikan bahawa pasukan berkenaan mampu menghadapi cabaran adalah tanggungjawab nasional.

"...The Army role in national security is to defend the state strategic interrest from external aggresion. This is best conducted though a concept

\footnotetext{
${ }^{1}$ Konsep Total Defence Adalah Doktrin Yang Telah Diamalkan Semenjak 1901 Lagi Sebagai Doktrin Pertahan Negara Moden Yang Telah Mula Diaplikasikan Di Sweden Yang Mewartakan Total Defence Act. Keterangan Mengenai Sejarah Dan Pengaplikasian Konsep Total Defence Di Malaysia Dapat Dirujuk Dalam Mohd Zackry Mokhtar (2006). Total Defence: Usaha Kolektif Memperkasa Pertahanan Negara. Perajurit. Jun.Hlm 38-43

${ }^{2}$ Konsep Total Defence Turut Dilaksanakan Oleh Indonesia Yang Memfokuskan Peranan Tenteradan Bukan Tentera Dalam Memeprtahankan Keselamatan Negara Yang Dikenali Sebagai 'Sishanta' (Pertahanan Negara Bersifat Semesta). Faktor Sejarah Penentangan Penjajahan Barat Iaitu Belanda Telah Menjadi Elemen Sejarah Yang Menjadi Tulang Belakang Aplikasi Doktrin Sishanta.

${ }^{3}$ Azman Abdul Razak (2009). Konsep Pertahanan Menyeluruh Di Malaysia: Cabaran Dan Masa Depan Angkatan Tentera Darat. Tesis. Kuala Lumpur:Fakulti Sastera Dan Sains Sosial, Universiti Malaya Hlm 17

${ }^{4}$ Hamzah Dolah (2006). Pembangunan Pertahanan Malaysia-Satu Pendekatan Menyeluruh. Perajurit. Disember.Hlm 52
} 
of total defence which would involved the Armed Forces, all the government and non-government agencies and even private concern..."

Menurut Azman Abdul Razak (2009) dalam Konsep Pertahanan Menyeluruh Di Malaysia: Cabaran Dan Masa Depan Angkatan Tentera Darat, konsep pertahanan menyeluruh merangkumi beberapa aspek penting seperti pertahanan angkatan tentera, pertahanan ekonomi, pertahanan sosial, pertahanan awam dan psikologi ${ }^{6}$. Dalam aspek pertahanan angkatan tentera, tanggungjawab barisan pertama dalam pertahanan melibatkan ATM. Justeru, pembangunan ATM memerlukan pembangunan yang besar yang bukan hanya tertumpu kepada anggota tetap semata-mata sebaliknya ia turut melibatkan pasukan simpanan, polis dan separa tentera. Dalam aspek pertahanan ekonomi, aspek ketahanan ekonomi adalah faktor yang memastikan keutuhan keselamatan dan kedaulatan negara. Dalam aspek pertahanan sosial pula ia melibatkan masyarakat untuk bersama menjaga kestabilan dan perpaduan kaum agar dapat melindungi keselamatan negara. Masyarakat juga perlu memiliki semangat patriotisme dan kesedaran terhadap kepentingan keselamatan yang tinggi agar dapat bersama membantu ATM melindungi negara. Dalam aspek pertahanan awam pula, pihak agensi, kerajaan dan swasta perlu memikul tanggungjawab dan mengambil pelbagai dasar untuk memastikan tanggungjawab memelihara keselamatan dan pertahanan negara dikongsi secara bersama. Dalam aspek pertahanan psikologi, masyarakat perlu memiliki ketahanan, keyakinan, semangat dan kekuatan mental yang tinggi dalam menghadapi pelbagai cabaran. Semangat nasionalisme perlu dipupuk mampu menghadapi apa jua keadaan termasuk peperangan.

Menurut Salim Ahmad Miandad (2002) dalam Self-Reliance In Malaysian Armed Forces Logistics System: An Essential Element To Enhance Defence Policy ${ }^{7}$ di bawah HANRUH telah dinyatakan beberapa komponen yang terkandung seperti Kesiapsiagaan keselamatan yang menjelaskan mengenai keperluan tentera, polis dan agensi keselamatan melindungi keselamatan awam disamping mempunyai anggota keselamatan yang terlatih, kredibiliti, mahir, bermotivasi dan bersedia menghadapi sebarang ancaman. Di bawah komponen ini ia menerangkan mengenai angkatan tentera tetap yang dibantu oleh angkatan simpanan dan sukarela yang besar. Angkatan pertahanan ini perlu mempunyai tahap kemampuan dan keupayaan yang tinggi dalam aspek peperangan konvensional $^{8}$ dan peperangan asymmetric. Selain itu, penyatuan dan perpaduan masyarakat yang memberi penekanan agar masyarakat hidup bersatu padu tanpa mengambil kira perbezaan kaum agama bangsa. Aspek integrasi kaum adalah penting bagi memastikan HANRUH dapat dijayakan. Strategi ini memerlukan kesiapsiagaan awam yang mana ia bermaksud kesediaan agensi awam, pihak swasta, penubuhan sukarela dan orang awam dalam memberi sumbangan melindungi nyawa dan harta benda ketika berlaku peperangan. Di bawah HANRUH juga aspek keutuhan ekonomi yang mana kerajaan dan swasta perlu berganding bahu serta bersatu padu untuk memastikan kekuatan dan kemampuan ekonomi terus bergerak ketika aman agar dapat membantu memenuhi keperluan ketika menghadapi krisis atau peperangan. Aspek keutuhan psikologi yang bermaksud kekuatan mental dalam memberikan komitmen terhadap keselamatan negara dan keyakinan yang tinggi terhadap kedaulatan negara. Ia adalah bagi memastikan rakyat dapat mempunyai ketahanan psikologi yang tinggi dalam menghadapi cabaran dan ancaman'. Menurut pendapat Salim Ahmad Bin Miandad (2002) :-

"As the self-reliance is the core of the National Defence Policy, the MAF has adopted a strategy encompasses this core matter-'self-reliance'. In defence self-reliance, the MAF has to build capabilities and force structure to meet the requirement as to provide security and defence of Malaysia. The strategies adopted are to fully utilise the force and capabilities that the

\footnotetext{
${ }^{5}$ Dipeik daripada Zulkefale A.Rahman (1998). Angkatan Tentera Malaysia: Arah Baru Menghadapi Cabaran Abad ke 21. Kuala Lumpur: Fakulti Sastera dan Sains Sosial .hlm 47

${ }^{6}$ Nasibah Harun (1997). Dasar Pertahanan Menyeluruh. Perajurit. September.hlm 8

${ }^{7}$ Kogila Balakrishnan (2008). Defence Industrialisation in Malaysia: Development Challenges and the Revolution in Military Affairs. Security Challenges, vol. 4, no. 4 (Summer 2008), pp. 135-155.

${ }^{8}$ Nugraha \& Loy (2013). Pembangunan Kependudukan untuk Memperkuat Ketahanan Nasional dalam Menghadapi Ancaman Asymmetric War, Direktorat Analisis Dampak Kependudukan, BKKBN, Jakarta. hlm 1-6

${ }_{9}^{9}$ Azman Abdul Razak (2009). Op.Cit.Hlm 20-22
} 
MAF possess. Besides that comprehensive strategy and tactics adopted in the defence of the country has to be planned and incorporated with all the other government agencies and private sectors so as to give a bigger 'punch' in any actions taken later"

\title{
Pertahanan Menyeluruh
}

Di dalam dokumen rasmi DPN yang diterbitkan oleh Kementerian Pertahanan mengenai dasar dan garis panduan pertahanan negara, kerajaan telah menyatakan mengenai perlaksanaan konsep pertahanan yang menjadi Konsep Pertahanan iaitu Pertahanan Menyeluruh (HANRUH). Pengunduran British daripada AMDA dan perjanjian FPDA yang tidak memberikan jaminan pertahanan kepada Malaysia telah mempengauhi Malaysia untuk mengamalkan prinsip self reliance ${ }^{10}$ dengan menggunakan strategi keselamatan dan pembangunan (KESBAN) yang menjadi perintis kepada wujudnya konsep pertahanan yang lebih luas iaitu Hanruh.

\section{Keselamatan dan Pembangunan (KESBAN)}

Konsep KESBAN strategi untuk membangunkan aspek keselamatan dengan membangunakan masyarakat dalam pelbagai aspek politik, ekonomi dan sosial. Ia adalah strategi yang membabitkan kesan langsung yang mana dengan meningkatkan pembangunan politik dan sosioekonomi, secara langsung akan meningkatkan aspek keselamatan. Malah konsep pertahanan ini juga merupakan konsep yang mengembleng tanggungjawab antara golongan tentera dengan bukan golongan tentera yang melibatkan masyarakat untuk turut serta mempertahankan keselamatan negara. Ancaman komunis yang menyaksikan kerajaan terpaksa melaksanakan undang-undang darurat (1948-1960) dan kebangkitan semula pemberontakan komunis (1968-1989) setelah British mengundurkan diri daipada timur Suez pada tahun 1967 telah menjadi faktor utama yang mempengaruhi perlaksanaan strategi KESBAN $^{11}$. Pengunduran British ini telah mempengaruhi ATM untuk mengambil tanggungjawab keselamatan secara penuh ke atas keselamatan negara dan memerlukan sokongan daripada masyarakat.

\begin{abstract}
"Kerajaan perlu mempunyai satu rancangan yang menyeluruh. Rancangan bukan sahaja meliputi keselamatan dan gerakan militeri tetapi merangkumi aspek politik, sosial ekonomi, pentadbiran, polis dan lain-lain perkara yang ada kaitannya dengan perang insurjensi ${ }^{12}$.
\end{abstract}

Dalam memastikan prinsip self-reliance dapat dicapai, MKN telah meluluskan cadangan melaksanakan strategi KESBAN dan perlaksanaan KESBAN telah diljalankan oleh Majlis Gerakan Negara (MAGERAN) semenjak tahun 1970 yang merupakan strategi pertahanan Malaysia secara komprehensif dengan melibatkan ATM, agensi kerajaan dan masyarakat. Aspek yang menjadi fokus adalah pembangunan masyarakat dan pembangunan keselamatan yang mana usaha ini adalah bagi menghadapi ancaman pemberontakan komunis yang menggunakan kawasan luar bandar sebagai pusat gerakan dan operasi. PKM telah menjadikan kawasan luar bandar dan pedalaman sebagai jaringan komunikasi dan untuk mendapatkan bantuan serta kemudahan bagi menjalankan penentangan terhadap kerajaan.

Salah satu usaha yang diambil oleh kerajaan adalah dengan memperkembangkan dan memperkukuhkan strategi Rancangan Brigg ${ }^{13}$ yang mewujudkan kampung-kampung baru yang

\footnotetext{
${ }^{10}$ Perajurit. (2012). Dasar Pertahanan Malaysia Satu Analisa. hlm. 1-8

${ }^{11}$ General Tan Sri Dato' Seri Panglima Hj Zulkifli bin $\mathrm{Hj}$ Zainal Abidin. (2015). Inculcating Professionalism in Defence for National Development: With Special Reference to KESBAN Concept. National Defence University, Malaysia. hlm. 1-3

${ }^{12}$ Nasibah Harun (Pnm). Dasar Pertahanan Menyeluruh, Sempena Hari Angkatan Tentera Malaysia. Perajurit....Hlm 6

${ }^{13}$ Nurul Huda Ariffin bin Muda. (1972). Darurat: Implikasinya Terhadap Kemasyarakatan dan Ekonomi di Tanah Melayu. Universiti Kebangsaan Malaysia. hlm. 73-80
} 
dikawal agar dapat mematahkan gerakan pemberontakan PKM. Selain itu, mewujudkan kampungkampung baru juga dapat digunakan sebagai strategi memisahkan identiti masyarakat dengan pemberontak disamping dapat menjadikan perkampungan baru ini sebagai kawasan penempatan yang dapat menjana ekonomi masyarakat dan keselamatan yang lebih terjamin. Kerajaan juga turut berusaha mencipta keyakinan masyarakat terhadap kerajaan dengan meningkatkan taraf hidup, pendapatan, aktiviti ekonomi dan keselamatan. Ia secara langsung akan memberikan kesedaran dan keyakinan masyarakat untuk memberikan sokongan kepada kerajaan memerangi pemberontakan komunis yang mengancam keselamatan negara.

Usaha penerapan KESBAN juga turut membabitkan penstrukturan semula masyarakat dan juga pentadbiran agar dapat memastikan objektif $\mathrm{KESBAN}^{14}$ dapat dicapai. Usaha ini telahpun wujud semenjak April 1950 lagi dengan penubuhan Majlis Peperangan Persekutuan (Federal War Council) ${ }^{15}$ bagi peringkat Persekutuan yang dianggotai oleh Pengarah Gerakan, Ketua Setiausaha, Pegawai Pemerintah Udara, Pesuruhjaya Polis, Setiausaha Pertahanan dan Pengarah Perisikan. Majlis Peperangan Persekutuan ini bertanggungjawab menghasilkan dasar dan sumber pertahanan dan akan dilaksanakan di peringkat negeri. Manakala bagi peringkat negeri pula ditubuhkan State and Settlement War Executive yang terdiri daripada Menteri Besar, Penasihat British, Pegawai Kanan Angkatan tentera, Ketua Polis Negeri dan Seorang Setiausaha.

Kerajaan juga telah menubuhkan pelbagai jawatan kuasa khas termasuk di Sabah dan Sarawak yang membabitkan negeri dan persekutuan yang turut membabitkan anggota keselamatan bagi memastikan usaha membangunakn masyarakat dan negara dan keselamatan dapat dicapai. Badan-badan ini adalah bertanggungjawab membuat perancangan, laporan, perlaksanaan dan pemantauan bagi memastikan proses perlaksanaan KESBAN dapat bergerak dengan berkesan. Melalui KESBAN jurang ekonomi antara penduduk di kawasan bandar dengan luar bandar dapat dikurangkan disamping mencipta aktiviti ekonomi dan kemudahan serta jaminan keselamatan yang baik dapat disediakan.

Ia secara tidak langung meningkatkan keyakinan masyarakat terhadap pemerintahan kerajaan dan memberikan sokongan kepada kerajaan dan mematahkan pemberontakan PKM. Sejajar dengan perkembangan semasa ancaman dalaman seperti pemberontakan PKM, pengisytiharan peta baru Pelantar Benua Malaysia pada 21 Disember 1979 dan pengisytiharan Zon Ekonomi Eksklusif (ZEE) Malaysia yang merangkumi 200 batu nautika dari pinggir pantai pada 25 April 1980, ancaman luaran khususnya komunis antarabangsa dan ketidakstabilan rantau telah mempengaruhi kerajaan untuk mempergiatkan usaha menangani ancaman dengan memperluaskan konsep atau strategi KESBAN ${ }^{16}$ bagi memastikan negara dapat bergantung pada diri sendiri adalah aspek keselamatan dan pertahanan. Ia adalah sejajar dengan pengamalan prinsip pertahanan self-reliance yang berusaha memastikan negara dapat mengelakkan diri daripada bergantung kepada kuasa luar dalam aspek kselamatan negara.

\section{Konsep Pertahanan Menyeluruh}

Sejajar dengan pengamalan prinsip pertahanan self-reliance dalam DPN ia telah melahirkan strategi KESBAN $^{17}$ semenjak tahun 1970 adalah konsep yang menetapkan penggunaan segala aset dan sumber negara bagi meningkatkan keupayaan sesebuah negara menghadapi pelbagai bentuk ancaman domestik dan luar sempadan yang mempengaruhi dan telah diperluaskan yang dikenali sebagai Pertahanan Menyeluruh atau total defence yang diperkenalkan semenjak Mei 1986. Antara ciri dalam strategi

\footnotetext{
${ }^{14}$ Ibid

${ }^{15}$ George II Q.R. (1915). Federal War Council.

Retrieved

at

http://www.austlii.edu.au/au/legis/wa/num_act/wca191559o1915176/wca191559o1915176.pdf

${ }^{16}$ General Tan Sri Dato' Seri Panglima Hj Zulkifli bin Hj Zainal Abidin. (2015). Inculcating

Professionalism in Defence for National Development: With Special Reference to KESBAN Concept.

National Defence University, Malaysia. hlm. 1-3

${ }^{17}$ Ibid
} 
HANRUH ini adalah pengaktifan pasukan keselamatan dan pertahanan awam simpanan (kerahan dan sukarela) dalam setiap organisasi yang berkaitan ${ }^{18}$.

\begin{abstract}
"Taking cognisance of Malaysia's strategic interests and the fundamentals of its defence policy, the MAF drew up a comprehensive strategy to achieve the aspirations envisaged by the nation in terms of defence. Hence, in this respect the concepts of forward defence, deterrence and total defence have been adopted as the defence strategy... The concept of total defence would further enhance and complement self-reliance" ${ }^{\prime 19}$.
\end{abstract}

Konsep pertahanan HANRUH (Total Defence) ini telah diamalkan oleh banyak negara seperti Sweeden ${ }^{20}$, Denmark, Finland, Singapura, Indonesia ${ }^{21}$, Singapura, Switzerland dan sebagainya. Namun dari segi perlaksanaan strategi ini antara negara berkenaan ia adalah berbeza mengikut aset dan sumber pertahanan yang dimiliki oleh sesebuah negara berkenaan. Walau bagaimanapun, dari aspek objektif adalah sama yang ia bertujuan menggembeleng semua aset-aset dan kekuatan negara dari segi ekonomi, sosial, politik, psikologi dan pertahanan awam di samping sistem pertahanan ketenteraan bagi mengukuhkan sistem pertahanan negara ${ }^{22}$. Perlaksanaan KESBAN $^{23}$ yang memberikan penemuan terhadap pembangunan negara dan keselamatan telah diperluaskan dalam strategi HANRUH yang mana dibawah HANRUH ${ }^{24}$, kerajaan telah memperkembangkan konsep total defence ini dengan mewujudkan anggota pertahanan sukarela, national service, Pertahanan Awam dan sebagainya bagi memastikan strategi HANRUH dapat dicapai. Penglibat golongan masyarakat, agensi dan ATM ini adalah model yang mana ia telah diperkembangkan pada era 1980-an yang dikenali sebagai konsep Pertahanan Menyeluruh (HANRUH) yang menggabungkan sumber pertahanan, ATM, agensi kerajaan dan swasta serta masyarakat secara keseluruhan. Strategi ini adalah berkaitan dengan usaha yang total dan bersepadu yang dilaksanakan oleh kerajaan, agensi bukan Kerajaan, sektor swasta dan memerlukan komitmen semua lapisan rakyat, dan tidak hanya oleh Angkatan Tentera dalam mempertahankan negara.

\footnotetext{
${ }^{18}$ Konsep total defence adalah doktrin yang telah diamalkan semenjak 1901 lagi sebagai doktrin pertahan negara moden yang telah mula diaplikasikan di Sweeden yang mewartakan Total Defence Act. Keterangan mengenai sejarah dan pengaplikasian konsep total defence di Malaysia dapat dirujuk dalam Mohd Zackry Mokhtar (2006). Total Defence: Usaha kolektif memperkasa pertahanan negara. Perajurit. Jun. hlm 38-43

${ }^{19}$ Salim Ahmad Bin Miandad (2002). Op.Cit.Hlm 32-35

${ }^{20}$ Konsep Total Defence adalah doktrin yang telah diamalkan semenjak 1901 lagi sebagai doktrin pertahan negara moden yang telah mula diaplikasikan Di Sweeden yang mewartakan Total Defence Act. Keterangan mengenai sejarah dan pengaplikasian konsep Total Defence di Malaysia dapat dirujuk dalam Mohd Zackry Mokhtar (2006). Total Defence: Usaha Kolektif Memperkasa Pertahanan Negara. Perajurit. Jun.Hlm 38-43

${ }^{21}$ Konsep Total Defence Turut Dilaksanakan Oleh Indonesia Yang Memfokuskan Peranan Tenteradan Bukan Tentera Dalam Memeprtahankan Keselamatan Negara Yang Dikenali Sebagai 'Sishanta' (Pertahanan Negara Bersifat Semesta). Faktor Sejarah Penentangan Penjajahan Barat Iaitu Belanda Telah Menjadi Elemen Sejarah Yang Menjadi Tulang Belakang Aplikasi Doktrin Sishanta.

${ }^{22}$ Azman Abdul Razak (2009). Konsep Pertahanan Menyeluruh Di Malaysia: Cabaran Dan Masa Depan Angkatan Tentera Darat. Tesis. Kuala Lumpur:Fakulti Sastera Dan Sains Sosial, Universiti Malaya Hlm 17

${ }^{23}$ General Tan Sri Dato' Seri Panglima Hj Zulkifli bin Hj Zainal Abidin. (2015). Inculcating Professionalism in Defence for National Development: With Special Reference to KESBAN Concept. National Defence University, Malaysia. hlm. 1-3

${ }^{24}$ Konsep Total Defence adalah doktrin yang telah diamalkan semenjak 1901 lagi sebagai doktrin pertahan negara moden yang telah mula diaplikasikan Di Sweeden yang mewartakan Total Defence Act. Keterangan mengenai sejarah dan pengaplikasian konsep Total Defence di Malaysia dapat dirujuk dalam Mohd Zackry Mokhtar (2006). Total Defence: Usaha Kolektif Memperkasa Pertahanan Negara. Perajurit. Jun.Hlm 38-43
} 
"...The Army role in national security is to defend the state strategic interrest from external aggresion. This is best conducted though a concept of total defence which would involve the Armed Forces, all the government and non-government agencies and even private concern... ${ }^{25,}$

Malah melalui strategi HANRUH, keselamatan negara sebagai tanggung jawab semua masyarakat dan tanggungjawab nasional. Sejajar dengan prinsip pertahanan self-reliance ${ }^{26}$, Malaysia berusaha ke arah meningkat dan membangunkan keupayaan ATM di samping menggalakkan kesedaran pertahan dan semangat patriotik di kalangan rakyat jelata.

\section{Rajah 1: Strategi HANRUH}

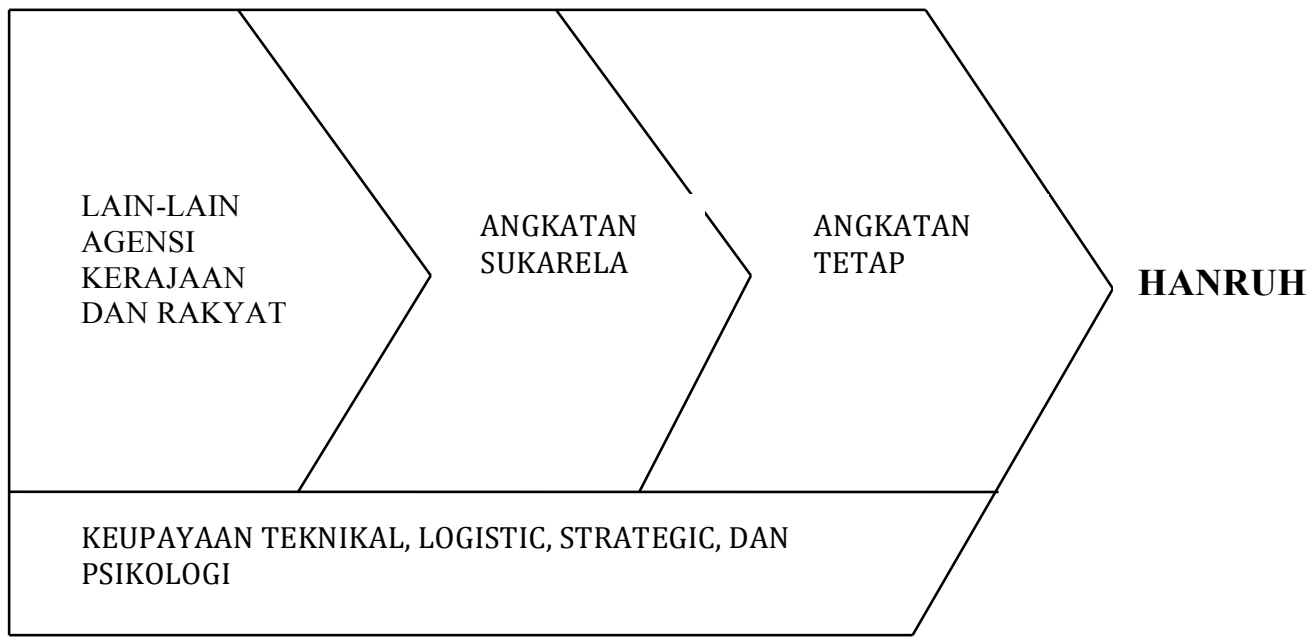

Di dalam konsep HANRUH, aspek pertahanan telah dikembangkan melibatkan pertahanan angkatan tentera, pertahanan ekonomi, pertahanan sosial, pertahanan awam dan psikologi ${ }^{27}$. Pertahanan ATM adalah merupakan pertahanan barisan pertama yang mana ATM akan memainkan peranan sebagai badan keselamatan yang utama dan dibantu oleh anggota keselamatan yang lain seperti pasukan simpanan, polis. Manakala barisan kedua terdiri dariapda anggota sukarela dan separa tentera dan barisan ketiga adalah masyarakat, sekor swasta dan lain-lain agensi kerajaan dalam mempertahankan negara yang menggunakan kelengkapan, teknik, logistik dan psikologi yang disediakan oleh kerajaan.

"HANRUH adalah konsep Total Defence versi Malaysia yang
diperkenalkan oleh Majlis Keselamatan Negara pada Mei 1986 bagi
merangka strategi pertahanan yang konkrit dan menyeluruh...HANRUH
menekankan penggunaan sumber manusia yang efisien, kemantapan
ekonomi, tindakan bersepadu daripada semua agensi kerajaan serta
mengadakan hubungan serantau dan antarabangsa yang baik sebagai
strategi memelihara keutuhan dan kedaulatan negara setiap masa." 28

Di dalam konsep HANRUH, pertahanan ekonomi telah menjadi salah satu aspek yang perlu diberikan perhatian yang mana pertahanan menyeluruh ini akan membabitkan pertahanan ekonomi. Ini kerana keruntuhan ekonomi akan membawa kepada ancaman keselamatan dan keruntuhan negara. Melalui pembangunan ekonomi ia juga akan memberikan peningkatan taraf hidup masyarakat, pendapatan negara dan membolehkan kestabilan dan pembangunan keselamatan dapat dipertingkatkan. Begitu juga

\footnotetext{
${ }^{25}$ Dipeik daripada Zulkefale A.Rahman (1998). Angkatan Tentera Malaysia: Arah Baru Menghadapi Cabaran Abad ke 21. Kuala Lumpur: Fakulti Sastera dan Sains Sosial .hlm 47

${ }^{26}$ Gene Sharp. (1992). SELF-RELIANT DEFENSE Without Bankruptcy or War. The Albert Einstein Institution. hlm 2-3.

${ }^{27}$ Nasibah Harun (1997). Dasar Pertahanan Menyeluruh. Perajurit. September.hlm 8

${ }^{28}$ Ibid. hlm 43
} 
dengan aspek ekonomi di bawah konsep HANRUH, kerajaan telah mempelbagai dasar pembangunan seperti dasar penswastaan ${ }^{29}$, Dasar Pandang ke Timur $^{30}$, Dasar Ekonomi Baru (DEB) ${ }^{31}$, Dasar Pembangunan Nasional ${ }^{32}$ dan sebagainya bagi meningkatkan aktiviti ekonomi kepada masyarakat yang akan mempengaruhi masyarakat untuk memberikan penumpuan kepada pembangunan negara berbanding menyokong gerakan pemberontakan. Dengan kestabilan politik dan keamanan yang diwujudkan, ia akan membolehkan aktiviti ekonomi negara dijalankan dengan pesat. Selain itu, dengan membangunkan ekonomi, program pembangunan sosioekonomi masyarakat dapat dipertingkatkan dan membuka peluang kepada pengukuhan ekonomi negara dengan adanya suasa yang aman dan dapat menarik masuk pelabur asing ke Malaysia ${ }^{33}$. Malah industri pertahanan juga turut dapat diperkembang dengan adanya aspek pertahanan ekonomi yang secara langsung dapat membolehkan Malaysia bergantung pada diri sendiri dalam aspek keselamatan ${ }^{34}$. Ia adalah sejajar dengan perlaksanaan prinsip pertahanan self-reliance ${ }^{35}$, kerajaan juga turut memperkemas konsep HANRUH dengan menjalankan pembangunan dan pemodenan ATM yang menjalankan pemodenan dariapda pasukan pertahanan yang beroreintasikan counter insurgency ${ }^{36}$ kepada conventional force ${ }^{37}$.

Di bawah konsep HANRUH juga di wujudkan Pertahanan Awam ${ }^{38}$ yang mana kerajaan telah mengambil pendekatan menubuhkan Jabatan Pertahanan Awam ${ }^{39}$ bagi memastikan nyawa dan harta orang awam dapat diselamatkan sekiranya berlaku masalah, ancaman dan peperangan. JPA bukan hanya menjalankan tugas ketika masa peperangan sebaliknya, tugas yang dietetapkan turut melibatkan ketika waktu aman. Dalam memastikan kerajaan dapat menggembeleng tenaga awam dalam aspek pertahanan menyeluruh, kerajaan telah mengambil pendekatan untuk memberikan kesedaran kepada masyarakat mengenai pertahanan negara dan tanggungjawab pertahanan sebagai tanggungjawab bersama. Penglibatan awam dalam pertahanan sekurang-kurang dapat menghalang pendaratan tentera musuh ke atas wilayah Malaysia disamping dapat mengelakkan musuh menjalan operasi serangan ke atas negara ${ }^{40}$.

Usaha ini dapat dilihat dengan tindakan kerajaan menubuhkan Pertahanan Awam, RELA, Rukun Tetangga $^{41}$, menjalankan program kesedaran dan keterlibatan masyarakat dengan memperkenalkan meningkatkan semangat patriotisme dan cintakan negara melalui Program Latihan Khidmat Negara

\footnotetext{
${ }^{29}$ Dipetik daripada Garis Panduan Penswastaan. (1985). Unit Perancang Ekonomi Jabatan Perdana Menteri. Hlm 1-2.

${ }^{30}$ Mohd Afendi Daud \& Junaidi Awang Besar. (2016). Meninjau kembali Dasar Pandang ke Timur Mahathir: Penelitian aspek perlaksanaan dan implikasi. Malaysian Journal of Society and Space. 12 issue $9(79-91)$.

${ }^{31}$ Uqbah Iqbal, Nordin Hussin \& Ahmad Ali Seman. (2014). Landskap ekonomi Malaysia sebelum

Dasar Ekonomi Baru: Peranan pelaburan Jepun. Malaysian Journal of Society and Space. 10 issue 2 (168 - 177) 168

${ }^{32}$ Yessi Anggraini. (2015). Perbandingan Perencanaan Pembangunan Nasional Sebelum Dan Sesudah Amandemen Undang-Undang Dasar 1945. Fiat Justisia Jurnal Ilmu Hukum. Volume 9 No. 1.

${ }^{33}$ Dipetik daripada Siaran Akhbar Statistik Pelaburan Langsung Asing Di Malaysia. (2015). Jabatan Perangkaan Malaysia.

${ }^{34}$ Yusni Yussof. (2011). Menghadapi pemikiran Anti Pertahanan \& tidak Patriotik. Perajurit. Mei. Hlm 56

${ }^{35}$ Ibid. hlm 2-3

${ }^{36}$ Lieutenant Colonel Baucum Fulk. (2011). An Evaluation Of Counterinsurgency As A Strategy For Fighting The Long War. Strategic Studies Institute. Hlm 1-2.

${ }^{37}$ Harry Gelman. (1989). The Soviet Turn Toward Conventional Force Reduction. A Project Air Force Report.

38 Dipetik daripada Akta Pertahanan Awam (Pindaan). (2016). Undang-undang Malaysia. Akta A1513.

${ }^{39}$ Dipetik daripada Kenyataan Media Angkatan Pertahanan Awam Malaysia (APM). (September 2016).

Penjenamaan Semula Jabatan Pertahanan Awam Malaysia (JPAM) kepada Angkatan Pertahanan Awam Malaysia (APM) dan Penggunaan Akronim Angkatan Pertahanan Awam Malaysia. Cawangan Perhubungan Awam \& Dokumentasi APM.

${ }^{40}$ Hamzah H.A (2006). Pembangunan Pertahanan Malaysia-Satu Pendekatan Menyeluruh. Perajurit. Disember. Sila rujuk dalam laman http://min-def.blogspot.com/2008/08/pembangunan-pertahananmalaysia-satu.html

${ }^{41}$ Majlis Keselamatan Negara Arahan No. 20 (Semakan Semula). Dasar Dan Mekanisme Pengurusan

Bencana Negara Majlis Keselamatan Negara. Jabatan Perdana Menteri. Hlm 29-31.
} 
$(\mathrm{PLKN})^{42}$, membuka peluang kepada golongan muda untuk menyertai anggota simpanan (PSS), anggota Pasukan Pegawai Latihan Sukarela (PALAPES) ${ }^{43}$ di pelbagai Institut Pengajian Tinggi (IPT), anggota Pasukan Latihan Anggota Sukarela (PLAS) di politeknik dan kolej. Malah, terkini terdapat cadangan agar Askar Wataniah (AW) ditempatkan di setiap kawasan parlimen bagi memastikan pengurusan, penyaluran maklumat dan bantuan dapat dijalankan dengan lebih berkesan sekiranya berlakunya peperangan. Selain itu aspek kekuatan pertahanan ATM juga adalah aspek yang penting dalam menjayakan strategi HANRUH $^{44}$. Pengkhususan perkhidmatan dan kemampuan untuk menjalankan operasi secara bersama juga yang melibatkan TDM, TLDM dan TUDM akan membantu kejayaan strategi HANRUH ${ }^{45}$. Selian itu pendekatan bukan ketenteraan seperti menjalinkan hubungan yang baik antara Malaysa dalam FPDA $^{46}$, dengan negara serantau dalam organisasi antarabangsa seperti $\mathrm{ASEAN}^{47}$ dan $\mathrm{PBB}^{48}$ dapat meningkatkan keselamatan negara.

\section{Perspektif Positif Terhadap Perlaksanaan HANRUH}

Bagi pendapat Nasibah Harun $(\mathrm{PNM})^{49}$ telah menyentuh mengenai strategi pertahanan menyeluruh dalam DPN. Strategi HANRUH ${ }^{50}$ bermula dengan perlaksanaan KESBAN $^{51}$ yang bertujuan bagi menghapuskan ancaman Parti Komunis Malaya disamping membangunkan pembangunan negara semenjak meletusnya Darurat (1948-1960). KESBAN adalah satu pendekatan Malaysia menangani ancaman dengan prinsip pertahanan berdikari yang memastikan keselamatan dan pertahanan negara dapat dilindungi dan mengurangkan pergantungan terhadap negara luar. Kerajaan telah mengambil pendekatan untuk memperkembang idea prinsip pertahanan berdikari daripada KESBAN kepada Pertahanan Menyeluruh yang mana tanggungjawab mempertahankan negara adalah melibatkan semua pihak rakyat, swasta dan kerajaan ${ }^{52}$. Sehubungan ini, Malaysia terus berusaha ke arah meningkat dan membangunkan keupayaan ATM di samping menggalakkan kesedaran pertahanan dan semangat patriotik di kalangan rakyat jelata ${ }^{53}$. Di dalam DPN, beberapa strategi telah digariskan bagi memastikan keselamatan dan kedaulatan negara terjamin. Antaranya ialah cegah rintang (deterrence). Azman Abdul Razak (2009) menyatakan : -

"Salah satu dasar yang digunapakai bagi mempertahankan kedaulatan negara iaitu Dasar Pertahanan Negara (DPN) yang telah diluluskan oleh Majlis Keselamatan Negara...Dasar ini telah menggariskan konsep dan halatuju Konsep Pertahanan Negara. Dalam abad ke 20-an telah wujud

\footnotetext{
${ }^{42}$ Mahadi Abu Hassan. (2005). Semangat Patriotisme Generasi Muda Melalui Program Latihan Khidmat Negara (PLKN). Universiti Teknikal Malaysia Melaka.

${ }^{43}$ Dipetik daripada keratan akhbar Berita Harian. (7 Julai 2013). Sertai PALAPES didik diri lebih disiplin.

${ }^{44}$ Malaysia's National Defence Policy. Dipetik daripada laman www.mod.gov.my/images/mindef/lainlain/ndp.pdf.

${ }^{45}$ Ibid

${ }^{46}$ Carlyle A. Thayer. (February 2007). The Five Power Defence Arrangements: The Quiet Achiever. Dipetik daripada laman www.regionalsecurity.org.au. Volume 3 Number 1.

${ }^{47}$ Mohamad Faisol Keling, Hishamudin Md.Som, Mohamad Nasir Saludin, Md. Shukri Shuib \& Mohd

Na'eim Ajis. (July 2011). The Development of ASEAN from Historical Approach. Asian Social Science. Vol. 7, No. 7.

${ }^{48}$ Zulhilmi Baharudin. (17 Mei 2006). Kenali Organisasi dan Peranan Pertubuhan Bangsa-Bangsa Bersatu. Dipetik daripada keratan akhbar Berita Harian. Terokai Ensiklopedia Dunia. Siri Ketiga, hlm 5.

${ }^{49}$ Nasibah Harun (Pnm). Dasar Pertahanan Menyeluruh, Sempena Hari Angkatan Tentera Malaysia.

Perajurit....Hlm 5-8

${ }^{50}$ Ibid

${ }^{51}$ General Tan Sri Dato' Seri Panglima Hj Zulkifli bin Hj Zainal Abidin. (Nov 2015). Inculcating

Professionalism in Defence for National Development: With Special Reference to KESBAN Concept.

Proceedings of 8th International Research Conference.

${ }^{52}$ Nasibah Harun (Pnm). Dasar Pertahanan Menyeluruh, Sempena Hari Angkatan Tentera Malaysia.

Perajurit....Hlm 8

${ }^{53}$ Ibid
} 
berbagai-bagai ancaman serius berpunca dari persekitaran. Bagi memenuhi keperluan kesejahteraan rakyat dan mengekalkan keharmonian kaum dan perhubungan dua hala, Malaysia telah menggariskan tiga konsep utama dalam sistem pertahanan negara iaitu; Konsep Cegahrintang (deterrence), konsep Pertahanan Hadapan (forward defence) dan konsep Pertahanan Menyeluruh (HANRUH), ${ }^{, 54}$.

Menurut Hamzah H.A (2006) $)^{55}$ ATM telah mengambil pendekatakan untuk memberikan kesedaran kepada masyarakat mengenai kepentngan dan tanggungjawab masyarakat bukan tentera untuk turut serta membantu ATM dan kerajaan melindungi dan mempertahakan keselamatan negara. Melalui HANRUH ia akan membolehkan penglibatan masyarakat bukan tentera untuk bersama-sama melibatkan diri menghalang dan mempertahakan kedaulatan dan keselamatan negara dariapda ancaman musuh. Malah proses mempertahankan negara ini adapat dijalankan dalam jangka masa yang berterusan agar musuh tidak dapat bertapak di Malaysia sekiranya ATM gagal menghalang pendaratan musuh.

\section{Perspektif Negatif Terhadap Perlaksanaan HANRUH}

Walaubagaimanapun, disebalik perspektif positif terhadap perlaksanaan HANRUH, terdapat juga pandangan penganalisis keselamatan yang memberikan perspektif negatif. Perlaksanaan strategi HANRUH adalah dibangunkan semenjak tahun 1970 hasil daripada perlaksanaan strategi KESBAN dan HANRUH dibangunkan pada tahun Mei 1986. Namun, konsep pertahanan menyeluruh yang diamalkan dalam DPN adalah sesuatu yang masih kabur. Ini kerana dari segi aplikasi strategi pertahanan ini hanya difahami oleh golongan tentera dan terhad kepada beberapa agensi. Malah, masyarakat juga tidak mengetahui mengenai strategi pertahanan menyeluruh yang merupakan strategi yang melibatkan masyarakat secara keseluruhan. Dari segi perlaksanaan, terdapat agensi-agensi kerajaan yang masih belum memahami dan mendengar mengenai HANRUH. Senario ini turut dinyatakan oleh K.S Balakrishnan (2009) yang mana strategi HANRUH yang diamalkan oleh kerajaan dalam DPN adalah sesuatu yang kabur dari segi penerimaan dan aplikasi oleh badan-badan kerajaan ${ }^{56}$. Strategi ini hanya difahami oleh ATM sebaliknya golongan bukan tentera tidak mengetahii mengenai HANRUH. Malah konsep ini turut tidak mendapat komitmen daripada agensi kerajaan dan tidak mendapat perhatian masyarakat. PLKN yang diperkenalkan pada tahun 2004 telah mendapat tentangan masyarakat yang mana anatara tahun 2004 hingga tahun 2007 permohonan ibu bapa atau penjaga telah memohon untuk menangguhkan dan mengecualikan daripada PLKN sebanyak 15 ke 30 peratus permohonan ${ }^{57}$.Malah pada tahun 2006 sahaja terdapat 4000 orang peserta tidak melaporkan diri ke Pusat Latihan Khidmat Negara yang menunjukkan masyarakat sukar memberikan komitmen kepada kerajaan dalam pembangunan pertahanan dan keselamatan negara ${ }^{58}$. Penerimaan ini dapat dilihat daripada kegagalan penerapan latihan ketenteraan oleh kerajaan dalam program PLKN apabila mendapat tentangan daripada masyarakat yang menganggap latihan ketenteraan tidak bersusuaian kepada peserta PLKN sedangkan program yang sama National Service Singapura adalah menggunakan latihan penuh ketenteraan bagi memastikan strategi total defence Singapura berjaya.

"Ketiadaan komitmen yang jitu dan positif daripada agensi-agensi kerajaan dan sambutan dingin oleh masyarakat setempat membenarkan tanggapan bahawa pertahanan keselamatan negara hanya terletak kepada bahu tentera

\footnotetext{
${ }^{54}$ Azman Abdul Razak (2009) dalam Konsep Pertahanan Menyeluruh Di Malaysia: Cabaran Dan Masa Depan Angkatan Tentera Darat). Op.cit.hlm 1

${ }^{55}$ Hamzah H.A (2006). Pembangunan Pertahanan Malaysia-Satu Pendekatan Menyeluruh. Perajurit. Disember. Sila rujuk dalam laman http://min-def.blogspot.com/2008/08/pembangunan-pertahananmalaysia-satu.html

${ }^{56}$ K.S Balakrishnan (2009). Malaysia’s Defence Policy, Military Modernisation And National Security. Dalam Abdul Razak Baginda (pnyt). Malaysia's Defence \&Security Since 1957. Kuala Lumpur: Malaysia Strategic Research Centre. hlm 117-118

${ }^{57}$ Ramai ibu bapa rayu hantar anak ke PLKN. Utusan Malaysia. 2 Januari 2012

${ }^{58}$ Pelatih ingkar diserah polis. Utusan Malaysia. 13 Julai 2006.
} 
semata-mata...Pada masa kini, pembangunan infrastruktur negara tidak berorientasikan kepada konsep pertahanan menyeluruh dan ia memerlukan kesedaran di peringkat pemimpin sehinggalah kepada rakyat. ${ }^{59,}$

Pandangan negatif, kekurangan komitmen daripada masyarakat adalah ukuran yang dapat digunakan untuk menilai penerimaan strategi HANRUH dan prinsip self-reliance ${ }^{60}$ di Malaysia. Justeru itu, masalah ini telah menunjukkan strategi pertahanan menyeluruh yang diamalkan dalam dasar pertahanan hanya di atas kertas sebaliknya ia tidak dilaksanakan dengan berkesan oleh kerajaan. Senario ini akan memberikan kesan kepada prinsip pertahanan self-reliance yang mana kegagalan strategi pertahanan ia akan turut mengagalkan prinsip pertahanan yang diamalkan.

\section{Rujukan}

Azman Abdul Razak (2009). Konsep Pertahanan Menyeluruh Di Malaysia: Cabaran Dan Masa Depan Angkatan Tentera Darat. Tesis. Kuala Lumpur:Fakulti Sastera Dan Sains Sosial, Universiti Malaya Hlm 17

Carlyle A. Thayer. (2007). The Five Power Defence Arrangements: The Quiet Achiever. Dipetik daripada laman www.regionalsecurity.org.au, 3(1).

Dasar Pertahanan Negara. Sumber : Kementerian Pertahan Negara. Dipetik daripada Garis Panduan Penswastaan. (1985). Unit Perancang Ekonomi Jabatan Perdana Menteri. Hlm 1-2.

Dipetik daripada Siaran Akhbar Statistik Pelaburan Langsung Asing Di Malaysia. (2015). Jabatan Perangkaan Malaysia.

Dipetik daripada Akta Pertahanan Awam (Pindaan). (2016). Undang-undang Malaysia. Akta A1513.

Dipetik daripada Kenyataan Media Angkatan Pertahanan Awam Malaysia (APM). (September 2016). Penjenamaan Semula Jabatan Pertahanan Awam Malaysia (JPAM) kepada Angkatan Pertahanan Awam Malaysia (APM) dan Penggunaan Akronim Angkatan Pertahanan Awam Malaysia. Cawangan Perhubungan Awam \& Dokumentasi APM.

Dipetik daripada keratan akhbar Berita Harian. (7 Julai 2013). Sertai PALAPES didik diri lebih disiplin. Malaysia's National Defence Policy. Dipetik daripada laman www.mod.gov.my/images/mindef/lain-lain/ndp.pdf.

General Tan Sri Dato' Seri Panglima Hj Zulkifli bin Hj Zainal Abidin. (2015). Inculcating Professionalism in Defence for National Development: With Special Reference to KESBAN Concept. National Defence University, Malaysia. hlm. 1-3

Gene Sharp. (1992). Self-Reliant Defense Without Bankruptcy or War. The Albert Einstein Institution. hlm 2-3.

George II Q.R. (1915). Federal War Council. Retrieved at http://www.austlii.edu.au/au/legis/wa/num_act/wca191559o1915176/wca191559o1915176.pdf

Harry Gelman. (1989). The Soviet Turn Toward Conventional Force Reduction. A Project Air Force Report.

Hamzah H.A (2006). Pembangunan Pertahanan Malaysia-Satu Pendekatan Menyeluruh. Perajurit. Disember. Sila rujuk dalam laman http://min-def.blogspot.com/2008/08/pembangunanpertahanan-malaysia-satu.html

K.S Balakrishnan (2009). Malaysia's Defence Policy, Military Modernisation And National Security. Dalam Abdul Razak Baginda (pnyt). Malaysia’s Defence \&Security Since 1957. Kuala Lumpur: Malaysia Strategic Research Centre. hlm 117-118

Kogila Balakrishnan (2008). Defence Industrialisation in Malaysia: Development Challenges and the Revolution in Military Affairs. Security Challenges, 4(4), 135-155.

Lieutenant Colonel Baucum Fulk. (2011). An Evaluation Of Counterinsurgency As A Strategy For Fighting The Long War. Strategic Studies Institute. Hlm 1-2.

Majlis Keselamatan Negara Arahan No. 20 (Semakan Semula). Dasar Dan Mekanisme Pengurusan Bencana Negara Majlis Keselamatan Negara. Jabatan Perdana Menteri. Hlm 29-31.

\footnotetext{
${ }^{59}$ Mohd Nooraimy Musa (2009) dalam Dasar Pertahanan Negara: Menganalisis Kemampuan Angkatan Tentera Malaysia Mendukukung Dasar Tersebut Pada Era Globalisasi. Perajurit.hlm4

${ }^{60}$ Ibid. hlm 2-3
} 
Mahadi Abu Hassan. (2005). Semangat Patriotisme Generasi Muda Melalui Program Latihan Khidmat Negara (PLKN). Universiti Teknikal Malaysia Melaka.

Mohamad Faisol Keling, Hishamudin Md.Som, Mohamad Nasir Saludin, Md. Shukri Shuib \& Mohd Na'eim Ajis. (July 2011). The Development of ASEAN from Historical Approach. Asian Social Science. 7(7).

Mohd Afendi Daud \& Junaidi Awang Besar. (2016). Meninjau kembali Dasar Pandang ke Timur Mahathir: Penelitian aspek perlaksanaan dan implikasi. Malaysian Journal of Society and Space. 12(9): 79 - 91.

Mohd Nooraimy Musa (2009) dalam Dasar Pertahanan Negara: Menganalisis Kemampuan Angkatan Tentera Malaysia Mendukukung Dasar Tersebut Pada Era Globalisasi. Perajurit.hlm4

Nasibah Harun (1997). Dasar Pertahanan Menyeluruh, Sempena Hari Angkatan Tentera Malaysia. Perajurit....Hlm 6

Nugraha \& Loy (2013). Pembangunan Kependudukan untuk Memperkuat Ketahanan Nasional dalam Menghadapi Ancaman Asymmetric War, Direktorat Analisis Dampak Kependudukan, BKKBN, Jakarta. hlm 1-6

Nurul Huda Ariffin bin Muda. (1972). Darurat: Implikasinya Terhadap Kemasyarakatan dan Ekonomi di Tanah Melayu. Universiti Kebangsaan Malaysia. hlm. 73-80

Pelatih ingkar diserah polis. Utusan Malaysia. 13 Julai 2006.

Perajurit. (2012). Dasar Pertahanan Malaysia Satu Analisa. hlm. 1-8

Uqbah Iqbal, Nordin Hussin \& Ahmad Ali Seman. (2014). Landskap ekonomi Malaysia sebelum Dasar Ekonomi Baru: Peranan pelaburan Jepun. Malaysian Journal of Society and Space. 10(2), $168-177$.

Yessi Anggraini. (2015). Perbandingan Perencanaan Pembangunan Nasional Sebelum Dan Sesudah Amandemen Undang-Undang Dasar 1945. Fiat Justisia Jurnal Ilmu Hukum, 9(1).

Yusni Yussof. (2011). Menghadapi pemikiran Anti Pertahanan \& tidak Patriotik. Perajurit. Mei. Hlm 56

Zulhilmi Baharudin. (17 Mei 2006). Kenali Organisasi dan Peranan Pertubuhan Bangsa-Bangsa Bersatu. Dipetik daripada keratan akhbar Berita Harian. Terokai Ensiklopedia Dunia. Siri Ketiga, hlm 5 .

Zulkefale A.Rahman (1998). Angkatan Tentera Malaysia: Arah Baru Menghadapi Cabaran Abad ke 21. Kuala Lumpur: Fakulti Sastera dan Sains Sosial .hlm 47 